\title{
Review on environmental and building services performance of urban heritage hospital
}

\author{
FX Teddy Badai Samodra, ${ }^{1, *}$ and Erwin Sudarma ${ }^{1}$ \\ ${ }^{1}$ Department of Architecture, Institut Teknologi Sepuluh Nopember, Kampus ITS Sukolilo Surabaya, \\ Indonesia
}

\begin{abstract}
Urban growth in today's development is an obstacle in providing the sustainable environment. Hospital as care facility takes an important and critical role in a livable environment for the users by its green building services. In conservation strategy, the building should concern on integration preserving the heritage value and planning of all care utilities. Therefore, this research reviews for sustainable and livable heritage hospital and were conducted through research phases as follows: Existing review, sustainable and green planning for critical building services, and environmental analysis using Ecotect Analysis and Matlab software environmental simulation. Dr. Soetomo Hospital is selected as the urban heritage object case. The results highlighted that the urban hospital should have design routes for building services integrated with mass management and architectural concepts as well as landscape design, and standardization of planning and system component life, designing the inner and/or outer rings will be potential planning. By conducting on to the existing high-density buildings evaluation, the building services master plan remains to be used is the zoning system pattern related with heritage conservation strategy. To anticipate the future projection, it is necessary to adjust the environmental performance because the utility system should accommodate the respective heritage for the requirement of facilities, capacity, and technology of green hospital concept.
\end{abstract}

\section{Introduction}

The mass order in a hospital master plan explicitly illustrates zoning areas of high-care, intermediate care and low-care, and daycare. As the most critical part of the Hospital site, the high-care building has the most important building served by the high-performance utility and require more supply capacity than the rest buildings. This illustrates the need for a non-generalist supply system but is divided according to the critical level.

The hospital building services concept should be planned to support the Joint Commission International (JCI) in the Facility Management and Safety standard, FMS.2, where hospitals need to develop a program that includes safety and security, hazardous materials control, emergency conditions response, fire safety, medical technology, and building services system [1]. Moreover, the green issues on urban development are the

* Corresponding author: fxteddybs@arch.its.ac.id 
main concern for future sustainable design. Recently, its consideration could save $10 \%$ consumption of energy by monitoring program of management for potential savings [2].

Most of the previous similar findings have recommended green technology for sustainable hospital [2-5]. However, related to the existence of the existing regulation that is translated into the building master plan, the conservation of the heritage has not been given by that results. Furthermore, it will be the challenge for building services plan and its management. Therefore, more than just recommending green idea as previous studies, this research proposes the novelty guidance related to environmental and building services reviews and planning for livable heritage hospital.

\section{Research method}

This research recommends master plan guidance for a special case of urban heritage incorporates with livable environment design. As shown in Figure 1, Dr. Soetomo Hospital as selected as the object case is a public hospital in Surabaya, Indonesia, which is developed to be focused on specialist and sub-specialist hospital after several years it services on public healthcare management. Furthermore, since has been established 1939 as a military hospital (Central Buggerlijk Ziekenhuis, CBZ), the building has potentially been decided as heritage building based on Decree Number 188.45/251/402.1.04/1996 Class A by Surabaya municipality and rapidly growing as a high-density mass order in its site (forbidden for new development intervention). Therefore, for every future proposal planning and design should be directed to conserve the history when building services should respond all challenges, both conservation issues and existing disorder of highdensity buildings.

The existing review and proposal were conducted through research phases as follows: (1). Existing review included heritage conservation concept generation by field observation and measurement using environment meter (Figure 2), (2). Sustainable and green planning for main and critical building services, and (3). Environmental analysis using Ecotect Analysis and Matlab software for the lighting and acoustics simulation.

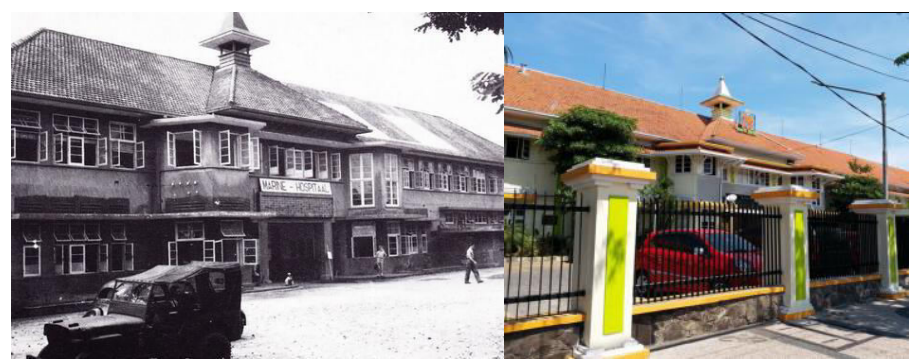

Fig. 1. Dr. Soetomo hospital in 1947 (left) and 2018 (right) [6].

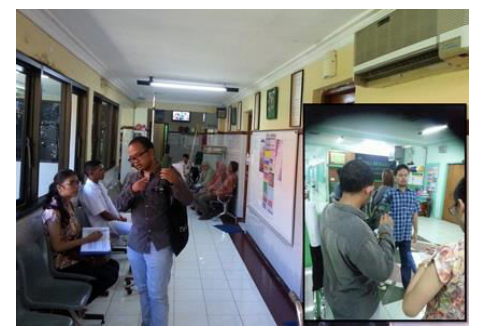

Fig. 2. Environment observation and measurement. 


\section{Results and discussions}

\subsection{Electricity system}

The design of this master plan for urban heritage should emphasize and pay attention to the reconstruction of the existing building and the locations. Therefore, the electrical system is planned with zone system according to existing condition and supply of power supply from the main source from State Electricity Company (PLN). Under these conditions, automatically the substation location and the Medium Voltage Network (TM) network route also need to be reset by matching the mass order to provide a larger green open space. As shown in Figure 3, the concept of electrical planning for the high-density existing problem should be recommended by fingers system where the network have to maintain the existing zone by adding capacity, according to the planning of the heritage or non-heritage buildings, centralize control (substations). Furthermore, it remains in the non-medical service area and minimizing the change of the repeater cable network which potentially disturbs the heritage conservation. In general, it needs to make relocation kiosk/substation (SS) and zoning of TM according to load character and to place the TM path around the inner ring-road and open area: Consider operational and maintenance.

In detail, it can be adjusted to the Technical Requirements of Infrastructure Installation of Electrical Hospital (Regulation of the Minister of Health of the Republic of Indonesia). It is the reference in fulfilling the technical requirements of electrical installation infrastructure to realize the hospital electrical installation infrastructure quality, in accordance with its function, reliable, and harmony with its environment [7].

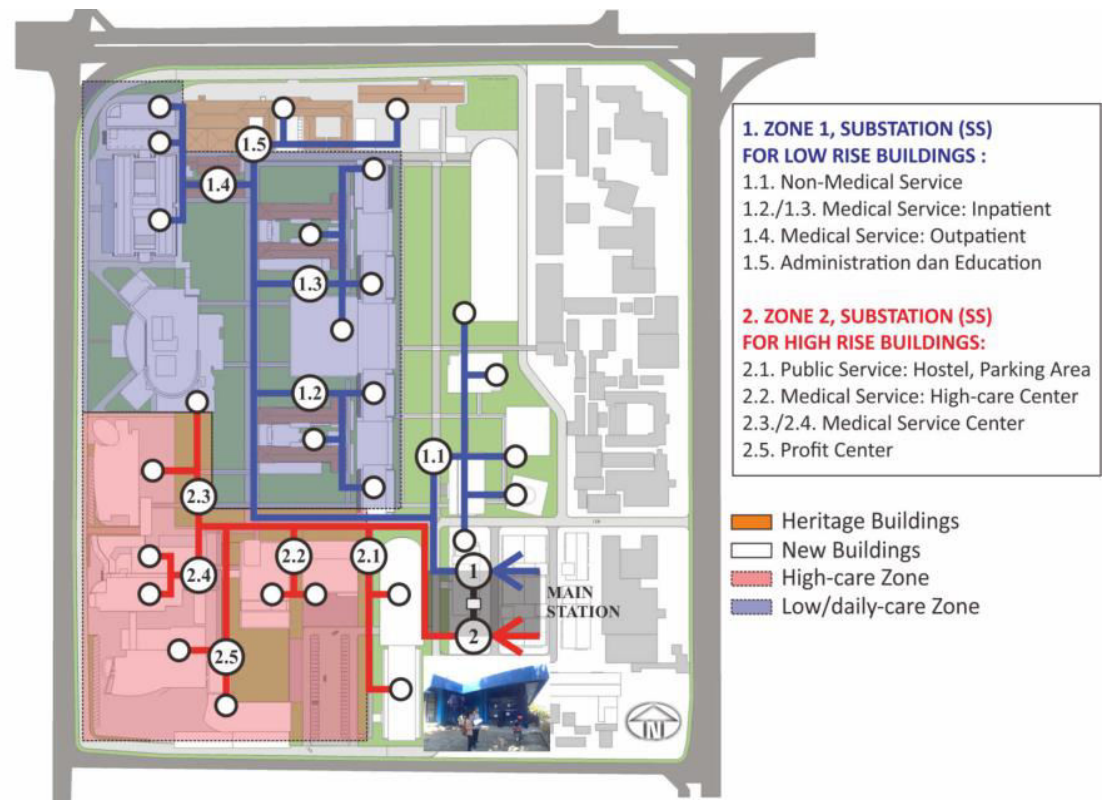

Fig. 3. Example of fingers system for electricity planning.

With the implementation of the above electrical concept, the main potential network route applied is aligned with the flow of circulation. The advantage that can be gained from this route is mainly on the clarity of the plot so that it will provide better access to operational activities and future maintenance. In terms of components, the condition of non-standard electrical components will obviously lead to operational and maintenance 
difficulties. Based on the evaluation results, the components that need attention are on the TM circuit breaker component, supplying the generator and other supporting components.

As one unified plan, the structuring of the TM network zone will include also the Low Voltage Network (TR) network served. The order of the radius system in the TR network is better to remember, the building blocks of mass are in the form of blocks and many floors. This system can simultaneously describe the network hierarchy better. Assuming the planned floor area in this master plan increases to $204 \%$ of the existing and $65 \%$ of the area will use the air conditioner, then maintaining continuity of electricity supply for highcritical buildings becomes very important. As a health service institution, continuous power supply is a must, besides relying on PLN, it is necessary to increase the reserve power capacity up to $100 \%$. Placement of reserve power through generators in the TM becomes very critical especially supporting buildings with high critical level (Electrical power is available 24 hours a day, 7 days a week, JCI Accreditation Standards for Hospitals, 2014, Measurable Elements of FMS.9.2). Furthermore, placing the generator set in TM, not in each building (TR) will support green hospital concept.

An emergency power system is required for all hospitals that intend to provide sustainable services in emergency conditions (JCI Accreditation Standards for Hospitals, 2014, Standard FMS.9.2.1). Such a system provides enough power to maintain important functions during power failures. It also reduces the risks associated with the failure. Emergency and reserve power sources are tested in a planned state that simulates actual load requirements. The improvements made when necessary, such as improving electricity services to areas with new medical technology or other equipment.

\subsection{Medical Gases}

The medical gas system as a typical system of hospitals requires improvement in connection with the master plan which is its integration with existing mass governance plans. Not much different from other utility systems, the arrangement of building masses in the master plan design will shift the gas central locations that exist today. In terms of aesthetics, the existing location is considered less precisely architectural because it is located in the facade facing area. On the other hand, the central location of the existing medical gas field is needed for mass placement as well as network or circulation.

As Figure 4, in detail the concept of medical gas planning for heritage hospital should create a centralized network and placing reserves in every building that requires medical gas by placing reserves for each zone or building). Moreover, centralizing gas supply and control for all types of gas in the non-medical service area are also conducted. The building service for the effective function should place gas pipelines around the inner ring road and open areas in order to respond the disordered mass with consideration on operational, aesthetic, and maintenance aspects. In addition, this is to support the safety factor as recommended by Standard FMS.7.1. from JCI, fire prevention through risk reduction, such as safe storage and handling potentially flammable materials, including combustible medical gases such as oxygen.

According to the Technical Guidance of Medical Gases and Medical Vacuum Installation System at Hospital, several things related to the design and installation of medical gas, among others should be installed with easy access to move cylinders, equipment, exit and enter to the location, be kept secure by doors or gates that can be locked or secured in other ways [8]. Moreover, the room should be protected by walls or fences of non-combustible material. For inside the building, it should be constructed and use non-flammable interior materials so that all walls, floors, ceilings, and doors should have at least 1-hour fire resistance; If electrical equipment is placed at or higher than 150 
$\mathrm{cm}(5 \mathrm{ft})$ above the floor to avoid physical damage, it must comply with applicable terms or standards; If a heating is required, it must be heated indirectly (eg. with steam or hot water). Meanwhile, it should also be equipped with shelves, chains, or other binders to secure each cylinder, whether connected or unconnected, full or empty, so as not to collapse, supplied with electric power that meets the requirements of the essential electrical system. Where supplied with shelves, the cabinets and the supports shall be made of non-flammable or combustible material.

The main problem of the medical gas system at the moment is the difference in shape and from the gas outlet used by the hospital. In the future development, this problem can be solved by standardizing the existing outlets, as well as equipping with pressurized air or suction air on the parts (spaces) where this network is needed. In accordance with the time span of the existing plan, then the supply capacity is likely to increase. If the current tube capacity is maintained, the central gas will require supply after continuous use. It is expected that with the installation of medical gas evenly distributed throughout the treatment area, manual use of the tubes is not required anymore.

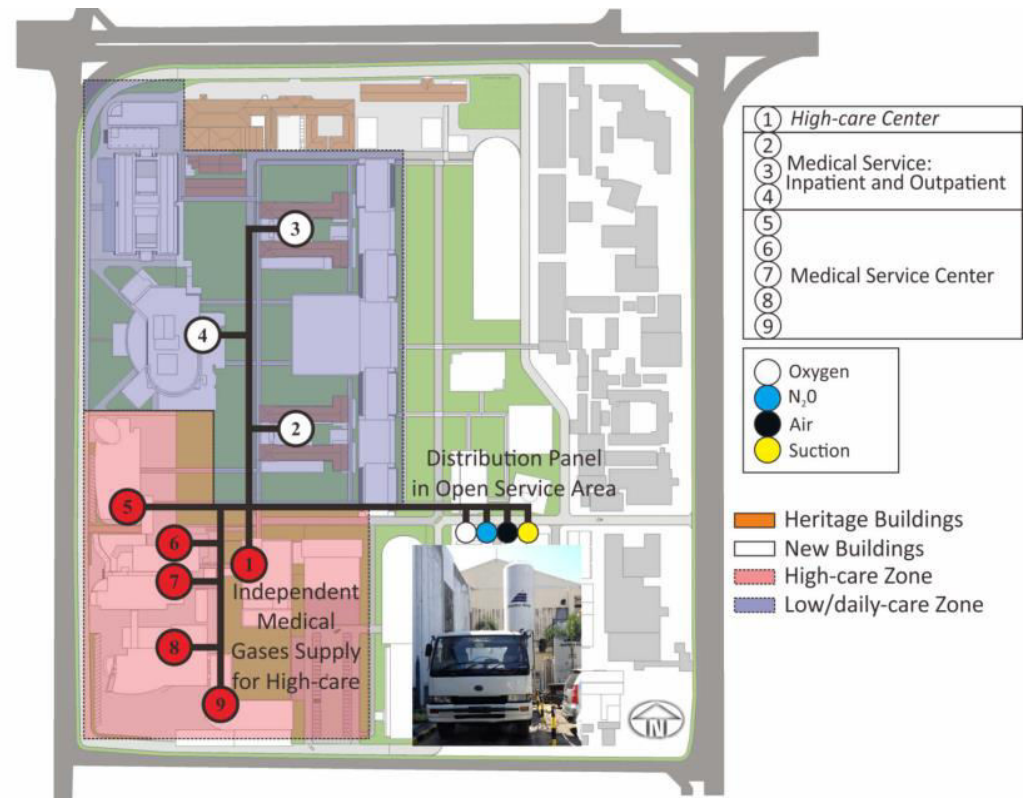

Fig. 4. Example of the medical gasses planning on the high-density environment.

\subsection{Fire safety}

Ongoing alertness is the beginning of prevention of fire hazards. Level of patient's physical ability and user density in Dr. Soetomo Hospital makes aspects of fire prevention and prevention is very important to set. In accordance with Standard FMS.7.1. from JCI, fire prevention programs include frequency of inspection, testing, and maintenance of fire protection and safety systems, as required, evacuation program of facilities in the event of fire or smoke, process to test all parts of the program every 12-month period, education required staff to effectively protect and evacuate patients when an emergency occurs, and participation of staff members in at least one fire safety test per year.

Conceptually, the efforts to support the program include 3 things, namely Prevention, Extinction, Evacuation. The details of the three concept strategies can be described in the 
following guidelines: First, a prevention strategy consists of passive which is compartmentation for fire load with centralized medical gas center, localized combustible building components when fire hazard is directed to make an anticipation of substation distribution (substation electric, public kitchen, hospital user with ease of access for evacuation. The resilience structure is supporting prevention method which should make a selection of fire-resistant building structures according to the functions it occupies. For active strategy, it recommends using detectors (centralization and tuning, improved performance of existing detectors).

Second, an extinguishment by sprinkler is used for all buildings above 3 floors. The existing fire extinguishers (APAR) already provided can be empowered and adjusted for a new building. As general planning, the use of integrated indoor and outdoor hydrants, Siamese placement on access entry and fire wells at the edge of the site could also be designed. To anticipate the high-density and damage of existing heritage building, the hydrant pipeline network is integrated with the circular and inner circulation of ring-road patterns supported by special fire pumps at each zone or high building. The last, an evacuation, tactic for occupants' safety, is implemented by providing an evacuation area or assembly point and utilizes an open area around the outer and inner ring-road is the best option to protect possibility to damage the heritage buildings.

The above concept is also adapted from the general provisions of the Hospital Infrastructure Technical Guidelines, Active Fire Protection System [9]. The extinguishing effort by planning the main ring-road route of the hydrant pipe conforms to the mass regulation guidance as shown in Figure 5.

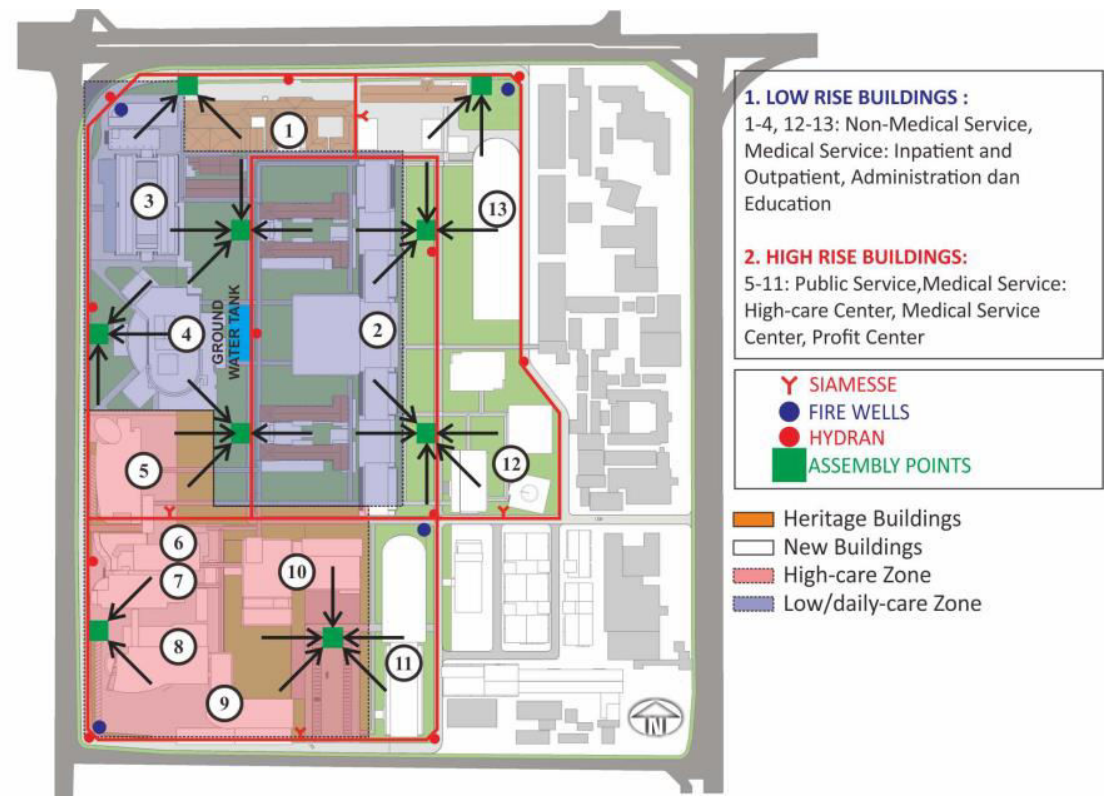

Fig. 5. Example of ring-road fire safety proposal.

\subsection{Environmental analysis}

Based on field observation and measurement, the average temperature in the building is $30.6^{\circ} \mathrm{C}$ and the humidity is $64.4 \%$ when the average wind speed is very low $(0.41 \mathrm{~m} / \mathrm{s})$, see Figure 6 . Ineffective air conditioning, the indication of the cause is opening window while Ministry of Health Standard No. 1204/MENKES/SK/X/2004 recommends range in 19- 
$30^{\circ} \mathrm{C}, 35-60 \%$ depending on the function [10]. Then need for the attention of the north side of each building is useful to anticipate the effects of solar radiation that will affect the indoor air quality (use of air conditioning). In other environmental aspects, high noise (average $58.8 \mathrm{dBA}$ ) is effected by the high frequency of building user activity as the main source (WHO standard: maximum $30 \mathrm{dBA}$, [11]). Based on Decree No.48/MENLH/11/1996 [12], the noise criterion is $55 \mathrm{dBA}$ for maximum tolerance while Ministry of Health Standard has varied greatly, as the patient room which is maximum 40 dBA during sleep. The building natural lighting is not in good performance, so it must use artificial lighting during daytime; average illumination for the hybrid design is 121.5 lux (standard from Ministry of Health Standard No. 1204/MENKES/SK/X/200 is: 100-200 lux depending on the function of the space).
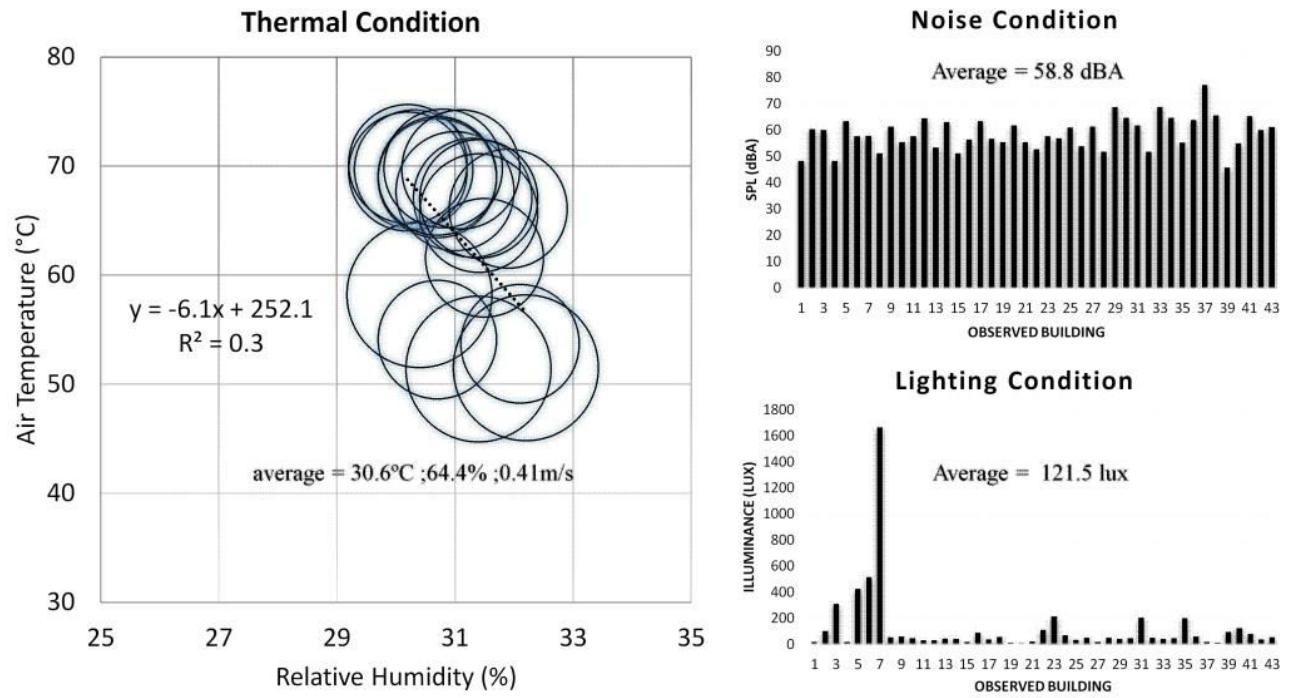

Lighting Condition

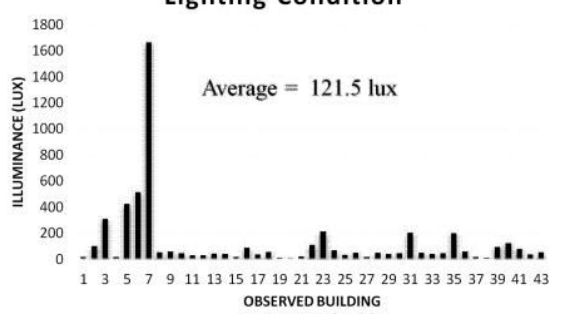

@source: 43 floor areas/buildings

Fig. 6. Environmental condition.

With respect to utility development, environmental conditions are not part of the discussion in the existing master plan. However, in addition to influencing the concept of air conditioning and lighting, the effective and efficient building noise control planned ahead in the master plan, environmental conditions effect on green hospital concept. In the site plan, clustering the building mass through courtyard design and generating night ventilation for heritage design will potentially improve the existing [13-14].

Originally, designed in the past, $38 \%$ of the existing building area use air conditioners. In general, the concept of air conditioning that supports green heritage hospital can be explained as follows: For efficient use, air conditioners with split placements are designated for low-rise buildings while high-rise buildings implement air conditioning with centralized control placement. Air conditioning systems for non-heritage high-rise buildings are determined by their characteristics or critical level. As usual, the building or service area is not installed by an air conditioner.

Whether with or without air conditioners, a well-treated wind flow such as a garden shade is recommended. It is already integrated with the concept of outer space. The layout of objects in the room is important for HVAC systems. The objects near the radiator or blower fan should be moved to free space. Furthermore, for efficient cooling load, placement of open orientations (windows for service buildings), outdoor (low-floor buildings) and outdoor chillers (high-floor buildings) that not exposed to much direct solar 
radiation should be implemented. As a consideration, updating the novel idea by Teke and Timur [14], water cooled chillers are evaluated as more efficient than water-cooled chillers if only the compressor costs are considered. However, a total annual savings of $58 \%$ can be achieved with water-cooled chiller using state-of-the-art technology from centrifugal and VSD compressors. The use of a material capable of passively dissipating heat and integrated with passive architectural and fire prevention concepts is recommended.

As a consequence of the concept, the air conditioning planning guide is set as follows: Split is used for rooms like Education, Administration, outpatient facility (IRJA), and nonmedical service (laundry, nutrition, pharmacy). The central system is suitable for Medical Service, High-care, Hostel, Medical Tower, and the other high-rise buildings). For non-air conditioning is for non-medical service.

With regard to lighting improvement efforts, the following strategies are suggested as future building planning guidance: The critical level of the building and even space also determines how natural or artificial light and its combinations are applied. Meanwhile, for non-critical spaces and buildings requiring high illumination levels, hybrid methods are strongly recommended. Consequently, the combination of open orientation and the lack of external space that barriers to the light of the sky become a necessity. This is to reduce the use of artificial lighting which is of course still used in small scale.

Some adapted recommendations to enhance better living environment are by replacing tungsten lamps with compact fluorescent lamps, old fluorescent tubes with new and low energy, electromagnetic ballasts with electronics and check the application of time control, light detector and skylight [2]. Figure 7 is an illustrative example of how the combination of openings and outer space can meet the needs of space lighting. Without artificial lighting, the building has enough illumination for general hospital needs. However, it should be noted that some fixed spaces must use an artificial lighting with special requirements related to the critical level.

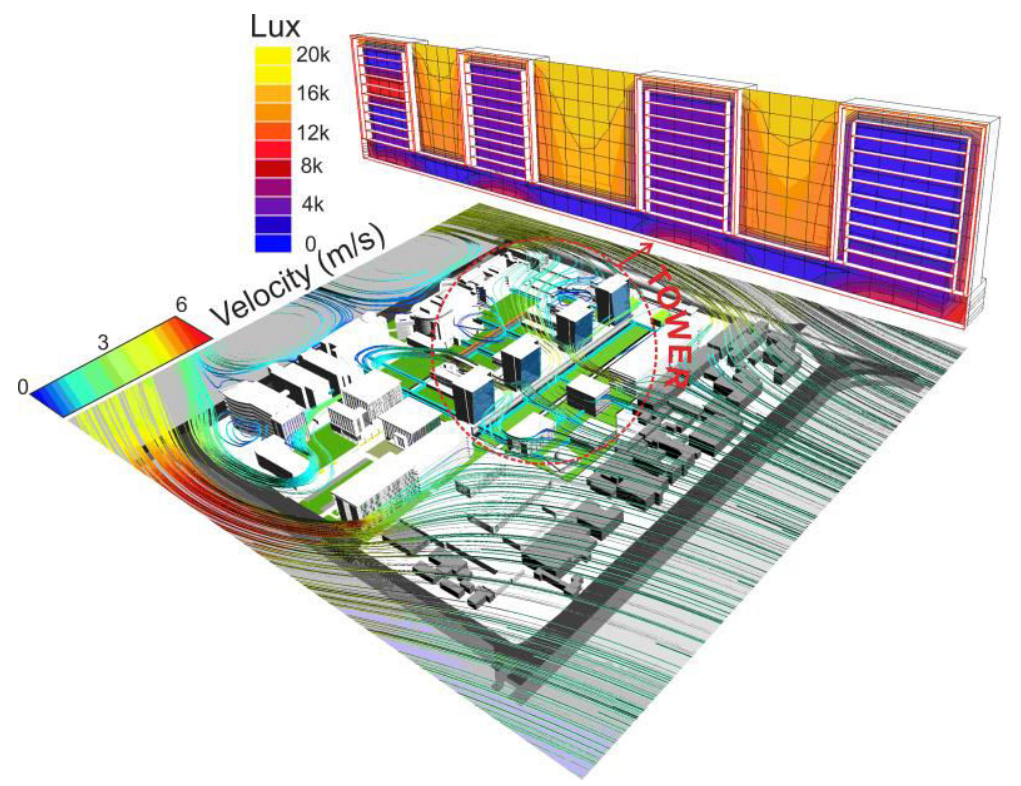

Fig. 7. Example for illumination and wind simulation for the high-rise. (source: Ecotect Analysis and Flow Design)

Associated with noise control, some guides integrated into the master plan can be applied to support the acoustics comfort achievement. The noise criteria will also be 
determined according to the critical level of the building and even space. Zoning service area as one of the sources of noise and non-service that has been integrated with the concept of mass arrangement. The addition of open areas, in addition to supporting the thermal comfort aspects (air conditioning efficiency), adding spacing between buildings that have different functions and activities, as well as to reduce the likelihood that the two attached buildings have a typical noisy source and a hazard criterion. The use of materials that can withstand traffic noise (have good Transmission Loss as a barrier), especially buildings adjacent to the highway as the main source of the noise. Zoning also applies in building scale to separate spaces with different noise criteria, but it must be spaced with due to medical demands. Some recommendations are to insulate the roof, draught proofing, and window shading [2]. Figure 8 is one example illustrates how the combination of distance and capability of building envelope can reduce noise. With a sample of the nearest distance of $20 \mathrm{~m}$ from a noisy source, the planned hostel uses concrete block walls as a noise barrier capable of reducing noise to below 15 dBA (still complying with WHO standards, Decree No. 48/MENLH/11/1996, and Ministry of Health standard No. 1204/MENKES/SK/X/2004). These findings, it could be integrated with the heritage design in case that $30 \mathrm{~mm}$ of the colonial walls thickness has existing better noise attenuation compared to the new one.

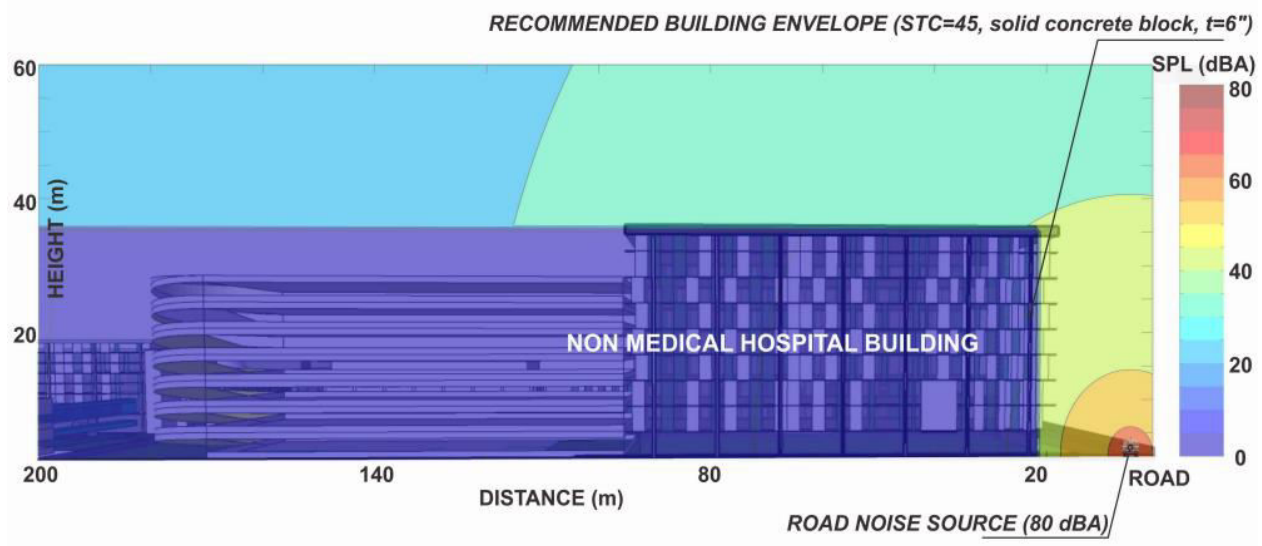

Fig. 8. Noise control.

(source: Matlab coding)

\section{Conclusions}

The evaluation of existing utility systems, several potentials and obstacles have been described as follows: The general electricity compliance still needs to be upgraded, even though on the basis of major electricity and reserve bills achieving for maximum limited needs. Moreover, the distribution of electricity is still not regular, supplying areas outside the tread. Meanwhile, there is no gases network to the low-rise building area, the distribution is done manually and there is no roof tank for high buildings. While the water pumps for fire prevention are only found in certain buildings, and the other areas still use water pumps; water distribution will be disrupted in case of fire. In addition, the passive fire protection systems using building structures and compartmentalization are not specifically designed integrated with the heritage building conservation strategy.

In general, the above potency and constraints can be directed as follows planning and design guidance: A good system pattern implemented based on existing building plan can be maintained and improved according to the application of green hospital concept which 
becomes the issue of master plan planning. Meanwhile, the recommendation for a better selection of building utility could save $58 \%$ as air conditioning system.

Related to the general hospital design, as obstacles, the general building services of an urban hospital have not been integrated with the mass management and architectural concepts as well as landscape, position or location of major sources spread, and standardization of planning. By conducting as evaluation results above, the part of the existing utility that remains to be used is the zoning system pattern for some of the existing utility systems related to heritage conservation strategy. However, to anticipate future development, it is necessary to adjust and analyze the environment because the criteria of utility system should be able to accommodate the need of facilities, capacity, and technology of green hospital concept.

\section{Acknowledgement}

This research is part of Excellent Public Services of Dr. Soetomo Hospital Master Plan 2016. The authors gratefully acknowledge this financial and technical support.

\section{References}

1. Joint Commission International, Joint Commission International Accreditation Standards for Hospitals $\left(5^{\text {th }}\right.$ Edition, USA, 2014)

2. D. Kolokotsa., T. Tsoutsos, S. Papantoniou, Advances in Building Energy Research 6,1 (2012)

3. T. Wang, X. Li, P-C. Liao, D. Fang, Energy, 103 (2016)

4. R. Saidur, M. Hasanuzzaman, S. Yogeswaran, H. A. Mohammed, M.S. Hossain, Energy 35 (2010)

5. V. Congradac, B. Prebiracevic, N. Petrovacki, Energy and Buildings, 69 (2014)

6. Dr. Soetomo Hospital Master Plan Report (Department of Architecture, Institut Teknologi Sepuluh Nopember, 2017)

7. Peraturan Menteri Kesehatan Republik Indonesia, No. 2306/MENKES/PER/XI/2011 Tentang Persyaratan Teknis Prasarana Instalasi Elektrikal Rumah Sakit

8. Direktorat Bina Pelayanan Penunjang Medik dan Sarana Kesehatan, Direktorat Bina Upaya Kesehatan, Kementerian Kesehatan. Pedoman Teknis Sistem Instalasi Gas Medik dan Vakum Medik di Rumah Sakit (2012)

9. Direktorat Bina Pelayanan Penunjang Medik dan Sarana Kesehatan, Direktorat Bina Upaya Kesehatan, Kementerian Kesehatan. Pedoman Teknis Prasarana Rumah Sakit, Sistem Proteksi Kebakaran Aktif (2012).

10. Keputusan Meteri Kesehatan Republik Indonesia No. 1204/MENKES/SK/X/2004 Tentang Persyaratan Kesehatan Lingkungan Rumah Sakit

11. B. Berglund, T. Lindvall, D. Schwela, K.T. Goh, Guidelines for community noise (World Health Organization (WHO), Geneva, 2000)

12. Keputusan Menteri Negara Lingkungan Hidup No. KEP-48/MENLH/11/1996 Tentang Baku Tingkat Kebisingan

13. I. Defiana, F. X. T. B. Samodra, W. Setyawan, IOP Conf. Ser.: Earth Environ. Sci. 126 (2018)

14. F. X. T. B. Samodra, I. Defiana, W. Setyawan, IOP Conf. Ser.: Earth Environ. Sci. 126 (2018)

15. A. Teke, O. Timur, Renewable and Sustainable Energy Reviews, 33 (2014) 